\title{
Toward A Successful Translation of The "Reduced" Anadiplosis in The Quranic Verses
}

\author{
Bacem A. Essam (Corresponding author) \\ Faculty of Al-Alson (Languages), Ain Shams University \\ PO box 13134, Abbassia, Cairo, Egypt \\ E-mail: literartrans@gmail.com
}

Doi:10.7575/aiac.alls.v.5n.6p.24

Received: 30/07/2014

URL: http://dx.doi.org/10.7575/aiac.alls.v.5n.6p.24

Accepted: 25/09/2014

\begin{abstract}
This study investigates the use of anadiplosis in both English and Arabic. It focuses primarily on outlining and defining the so-called "reduced" anadiplosis in some Quranic verses. The study investigates, too, the most popular English translations of them, highlighting the mismatches between the original holy text and its translations. The Quranic "reduced" anadiplosis is subtly elaborated to show how far it serves textual, semantic and stylistic functions. Evidently, at least one of these elements, if not more, is lost in the translation.

Essential to account for the source of dimly lit culpable background is to understand the philosophical and linguistic perspectives and predisposing factors of such a conflict. The paper traces back, etymologically and deductively, the origin of this manacle and proceeds to propose two suggested strategies toward overcoming this awkward status quo in translation.
\end{abstract}

Keywords: Quran translation, anadiplosis, Arabic "reduced" anadiplosis, stylistic variants and cognitive linguistics

\section{Introduction}

Anadiplosis, according to Dupriez (1991:36), refers to the repetition of a word or words in successive clauses in such a way that the second clause starts with the same word which marks the end of the previous clause. The Arabic language uses a variant or a modification of this literary device: the "reduced" anadiplosis. The infrequent use of this device either in English or its variant in Arabic makes it less knowable. That is why most of translators failed to render it stylistically and semantically in their translations.

This study investigates the Quranic verses in question and contrasts three of the most famous translations in relation to the original meaning. Unfortunately, all translations failed to render the stylistic and semantic content in every verse. This paper is technically analyzing the imperceptibly erroneous translations; highlighting some basic theoretical concepts and outlining some literary fundamentals. The study proceeds until eventually suggesting two simple techniques toward a successful translation.

\section{Research questions}

2.1 How far does the use of anadiplosis differ in English and Arabic?

2.2 As a rhetorical device, does anadiplosis have linguistic variants?

2.3 Were the Quranic translations successful in rendering the "reduced" anadiplosis in English?

2.4 How far can the mistranslation of the "reduced" anadiplosis in Quran affect the semantic, textual, and stylistic levels?

2.5 What are the suggested strategies toward a faithful translation of the Quranic "reduced" anadiplosis?

\section{Theoretical framework}

\subsection{The scope and usage of anadiplosis}

According to Preminger (1993:48), "Anadiplosis or epanadiplosis (Greek: $\alpha \dot{\nu} \alpha \delta i \pi \lambda \omega \sigma 1 \varsigma$, "doubled back") is a figure of word repetition that links two phrases, clauses, lines, or stanzas by repeating the word at the end of the first one at the beginning of the second". Graphically, it can be schemed as; __ W / W__ where "W" stands for word(s). Preminger cites some poetic examples of this powerful device to clarify its mechanics of being a rhetorical liaison thereby lines are made memorable. In Milton's "Samson Agonistes" [ Lit. Samson the agonist] (1671), we read:

Retiring from the popular noise, I seek

This unfrequented place to find some ease-

Ease to the body some, none to the mind

From restless thoughts, that, like a deadly swarm

Another example is read in Walt Whitman's "Song of Myself" (1892 version): 
Behold, I do not give lectures or a little charity,

When I give I give myself.

In Milton's poem, the word "ease" was repeated at the end of line 17 and the opening of line 18 to act a liaison that overemphasize Milton's “Unreachable mundane EASE”. In Whitman's transcendental poem, the phrase "I give" occurs at the end of the first clause and marks the beginning of the following clause in line 999 to highlight his altruistic and philanthropic attitude. Generally speaking, anadiplosis is frequently observed in the highly qualified texts, rhetoric speeches and modern "well-structured" discourses. The series of using the anadiplosis is called concatenation which is more musical.

Anadiplosis is also well-known in other languages. In French, we can read Maurice Maeterlinck's line "Ô ce verre sur mes désirs! Mes désirs à travers mon âme !" ( Verre ardent in Serres chaudes). In German, we may read Goethe's line "Mit dem Schiffe spielen Wind und Wellen, Wind und Wellen spielen nicht mit seinem Herzen." [Lit. With the ships play wind and waves, wind and waves do not play with his heart]. In Spanish, Miguel Hernández says "Mi sien, florido balcón / de mis edades tempranas, / negra está, y mi corazón, y mi corazón con canas.”, siglo XX [Lit. My temples, ornate balcony / my early ages /are black, and my heart, and my heart with gray]. The classical Arabic example are:

(1) The prophetic Hadith that teaches good manners:

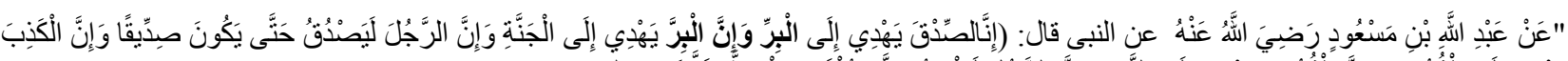

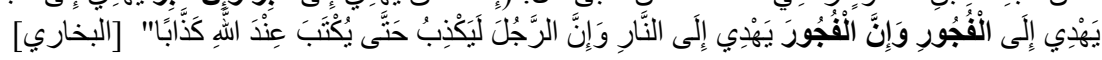

Translation: Narrated 'Abdullah ebn Masoad: The Prophet said, "Truthfulness leads to righteousness, and righteousness leads to Paradise. And a man keeps on telling the truth until he becomes a truthful person. Falsehood leads to wickedness, and wickedness leads to the (Hell) Fire, and a man may keep on telling lies till he is written before Allah, a liar ".[Bukhari: Volume 8, Book 73, Number 116]

(2) The Quranic verse from an-Noor Chapter [Lit. Light]

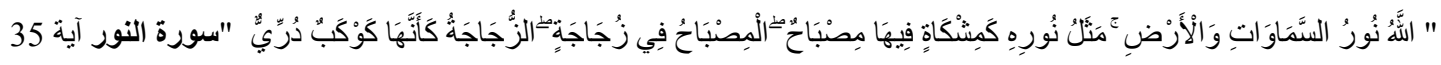

[Shakir 24:35] Allah is the light of the heavens and the earth; a likeness of His light is as a niche in which is a lamp, the lamp is in a glass, (and) the glass is as it were a brightly shining star. . .

[Pickthall 24:35] Allah is the Light of the heavens and the earth. The similitude of His light is as a niche wherein is a lamp. The lamp is in a glass. The glass is as it were a shining star. . .

[Yusuf Ali 24:35] Allah is the Light of the heavens and the earth. The Parable of His Light is as if there were a Niche and within it a Lamp: the Lamp enclosed in Glass: the glass as it were a brilliant star. .

The above translations have impressively recapitulated the stylistic device and the affected meaning of the original texts and rendered the same equivalence in the target language. Example (2) is delivered to point out, too, how anadiplosis can anadiplose to give a concatenation.

Additionally, there is an Arabic variant of anadiplosis that, unlike English, denotes the ability of a word, a phrase or a clause to express a bilocation, serving double purposes where it functions as an anadiplosis reduced within itself. The repetition is omitted for its easy conclusion.

\subsection{Philosophy of Languages}

According to Routledge Dictionary of Language and Linguistics (1996: 58), Anaphora is "a linguistic element which refers back to another linguistic antecedent in the coreferential relationship. The occurrence of anaphoras is considered to be a characteristic property of texts; it produces textual coherence". Thus, Anaphora is a linguistic device that is used for textual emphasis and artistic confirmation. It, moreover, adds a lovely rhythm to the prominent idea or argument in question.

In D. H. Lawrence's intriguing short story "The Princess", Anaphoric theory is highly enabled.

"She was erect, ..., she seemed like a changeling beside her big, handsome, slightly mad father. She dressed very simply, .... She had exquisite little hands,... She was rather given to wearing cloaks and capes, ...

She looked as if she had ...

She wanted to descend to the cabin ... She wanted to see the wild animals ..."

The repetition of the subject "she" is coherently linking sentences and successive paragraphs. The repetition of "she wanted" is another anaphoric example making the heroine the heart of the event. In the same vessel, An excerpt of Nasser's rhetorical speech reads:

Arab nationalism is not Gamal Abd al-Nasser, it is not Shukri al-Quwatli, it is not any particular leader. It is stronger than all of this. It is you my friends, the Arab people. Before today, I had not even met you. However, in all your eyes I see the spirit of nationalism rising up, I see a deep belief in it. I see this; I see that every one of you is profoundly convinced.

The concept of using the anaphoric theory is, thus, established in the Arabic language and so does English. Similarly, the anadiplosis is used in both languages as a vehicle that is excellent at crystalizing the discussed concept. The Quranic verses read in al- 'Alaq chapter [Lit. The Clot] 
Most of the translations are stylistically rendering it very poorly as follows.

[Shakir 96:15-16] Nay! if he desist not, We would certainly smite his forehead, A lying, sinful forehead.

[Pickthall 96:15-16] Nay, but if he cease not We will seize him by the forelock - The lying, sinful forelock.

[Yusuf Ali 96:15-16] Let him beware! If he desist not, We will drag him by the forelock,- A lying, sinful forelock.

A simple structural rearrangement would've maintained the integrity of the literal device. However, if such translations failed to render the most straight-forward example, why would we expect a stunning success in the hotter water.

Eloquent reduction, instead of anaphorically repeating word roots, is also evident within the Arabic syntax. An archetypal example of this trend is the cognate accusative structure (the internal object or الدفعول المطلق) and the prointernal object. The internal object is simply a morpho-syntactic device of intensifying an action by following the verb with its corresponding verbal noun with or without a modifying adjective(s). An example of the internal object is سلوكا مأساويا (e.g., I behaved in a tragic behavior). Traditionally, the nomination of the noun is preferably replaced or omitted. The English attitude replaces the noun by the word "way" because not every repetition is advocated. The Arabic syntax offers some alternatives via using the varieties of the pro-internal object. The aforementioned example can be rendered as "I behaved in a tragically behavior" or "I behaved that behavior" or "I behaved the most dramatic". Lucidly, we can do without repetitions that inherit the sense of redundantly sheer verbosity and notorious prolixity.

In the same vein, the anadiplosis can be rhetorically reduced. Think of it as a variant within the Arabic language. This Arabic variant, unlike English, would denote the ability of a word, a phrase or a clause to express a bilocation, serving double purposes where such word(s) function(s) as an anadiplosis reduced within itself. For applying this reduction vividly, let's cite two examples. The first one is captured from Vladimir Nabokov's "Lolita",

"What I present here is what I remember of the letter, and what I remember of the letter I remember verbatim (including that awful French). It was at least twice longer."

The other example is cited from Shakespeare's Sonnet CXXIX in which an anadiplosis is employed by repeating the word "mad" at the end of line 8 and the inception of line 9:

Past reason hunted, and no sooner had

Past reason hated, as a swallow'd bait

On purpose laid to make the taker mad;

Mad in pursuit and in possession so;

If it were composed in Arabic, the Arabic notion would graphically do as follows: (1) "What I present here is *what I remember of the letter*, [and what I remember of the letter] I remember verbatim. (2) On purpose laid to make the taker *mad*; [Mad] in pursuit and in possession so...). These asterisks are pedagogically used. This tutorial draft points out that we can do without the repetition once we highlighted the connecting word "mad".

Accordingly, the so-called "reduced" anadiplosis device serves both emphatic and linking purposes. While Preminger distinguished between the two values within the English text. Ellipsis is always, according to Thompson's functional grammar (2013), a sign of markedness. That is why this reduced device is usually emphatic. The Quranic marks specify a symbol that is similar in shape to the "therefore sign" in order to highlight this kind of reduction or assimilation.

\section{Practical analysis}

This paper aims not at establishing or proving any superiority of one language over the other. The objectives of this research do neither long for coining a new term nor inventing a new literary device nor diplomatically matching two heterogeneous concepts. This paper, however, aims at the comparative best-matching of the stylistic devices of both Arabic and English hinging on a concrete etymological and linguistic background.

In this section, the standard examples of the verses that exhibited the so-called "reduced" anadiplosis are enumerated, along with three translations of marvelous worldly success and recognition. After every example, the three translations will be following using the same order every time before the commentary appears. The commentaries are based on two prominent exegeses; namely Ebn Catheer's and Al- Qorttobi's. However, this analysis aims at magnifying the translation gap semantically and syntactically in all examples - a case that can be solved using one of the suggested strategies in the next section.

Example 1:

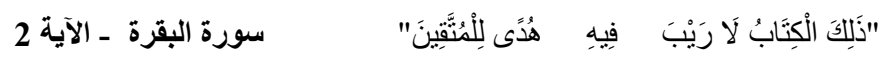

[Shakir 2:2] This Book, there is no doubt in it, is a guide to those who guard (against evil).

[Pickthall 2:2] This is the Scripture whereof there is no doubt, a guidance unto those who ward off (evil).

[Yusuf Ali 2:2] This is the Book; in it is guidance sure, without doubt, to those who fear Allah;

\section{Commentary:}

This Quranic verse anadiploses syntactically and semantically at the phrase "فئهِ" [translated: in it/ whereof/ in it]. To simplify, the verse contains two sentences that are syntactically connected: (1) this book/scripture has no doubt in it. 
Some suggested a stylistic meaning of "for this book, Show no doubt in it!" (2) In it [the book/scripture], there is a guidance (un)to those who fear Allah/ guard/ward (off evil). Obviously, the so called "reducing" anadiplosis emphasized the fact that both sentences are true by not repeating "in it".

Shakir's translation shifted to enhance the second clause and it would have been better if he could've said This Book, there is no doubt in it, has a guide". Pickthall's translation grammatically shifted the conjunction with absolute distortion of the stylistic device. Yet the affected meaning is near. Yusuf has structurally rearranged the sentence

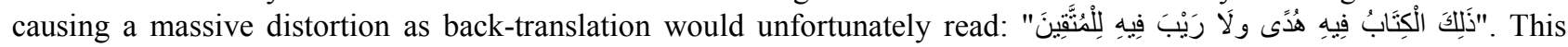
translation swept other stylistic readings away, confining the meaning to his exact understanding.

Example 2:

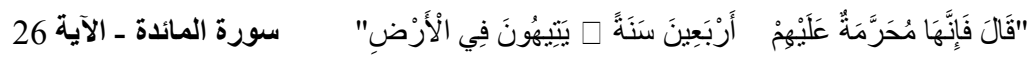

[Shakir 5:26] He said: So it shall surely be forbidden to them for forty years, they shall wander about in the land ...

[Pickthall 5:26] (Their Lord) said: For this the land will surely be forbidden them for forty years that they will wander in the earth, bewildered ...

[Yusuf Ali 5:26] Allah said: "Therefore will the land be out of their reach for forty years: In distraction will they wander through the land. .

\section{Commentary:}

This Quranic verse anadiploses syntactically and semantically at the phrase “ “'ارَبَعِينَ سَنَفة [translated: for forty years]. To illustrate, the verse contains two sentences that are syntactically connected; (1) it/the land shall/will surely/ therefore be forbidden to them/ out of their reach for forty years. (2) For forty years, they shall wander (about in/ through) the land. Evidently, the so called "reducing" anadiplosis emphasized the fact that both sentences are true by not repeating "for forty years".

Shakir's translation shifted to enhance the first clause and implied no conditionality/stipulation about the timing of their wandering. Pickthall's translation uses the linking word "that" to compensate for the stylistic conjunction of the two clauses. However, this translation failed to imply the emphasis and stylistic value. Yusuf uses colon as a punctuation mark to be a linking asset. However, his translation not only the time adjunct but the entire clause as well: which is not the case in the source text.

Example 3:

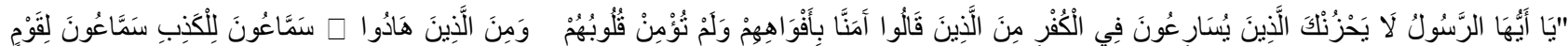
أَخَرِينَ " سورة المائدة ـ الآية 41

[Shakir 5:41] O Messenger! let not those grieve you who strive together in hastening to unbelief from among those who say with their mouths: We believe, and their hearts do not believe, and from among those who are Jews; they are listeners for the sake of a lie, listeners for another people...

[Pickthall 5:41] O Messenger! Let not them grieve thee who vie one with another in the race to disbelief, of such as say with their mouths: "We believe," but their hearts believe not, and of the Jews: listeners for the sake of falsehood, listeners on behalf of other folk. . .

[Yusuf Ali 5:41] O Messenger! let not those grieve thee, who race each other into unbelief: (whether it be) among those who say "We believe" with their lips but whose hearts have no faith; or it be among the Jews,- men who will listen to any lie,- will listen even to others. . .

\section{Commentary:}

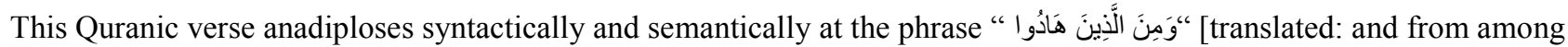
those who are Jews / and of the Jews/ or it be among the Jews]. To clarify, the verse contains two sentences that are syntactically connected; (1) let not those grieve you who strive together in hastening/race (in)to unbelief from among those who say with their mouths: We believe, while their hearts do not believe and FROM AMONG THOSE WHO ARE JEWS. (2) FROM AMONG THOSE WHO ARE JEWS, [some] are listeners for the sake of a lie, listeners for others. Again, the so called "reducing" anadiplosis emphasized the fact that both sentences are true by not repeating "from among those who are Jews".

Shakir's translation was inaccurate and ambiguous especially with the use of the pronoun "they" that can refer to one or all of the aforementioned categories: a generalization that is not meant in the original verse. Pickthall's translation is more specific to the Jews. However, not all "and of the Jews" are accused of listening to lies and others. Yusuf has oddly used double punctuation marks (, -) that served the syntactic and affective meaning the best.

Example 4:

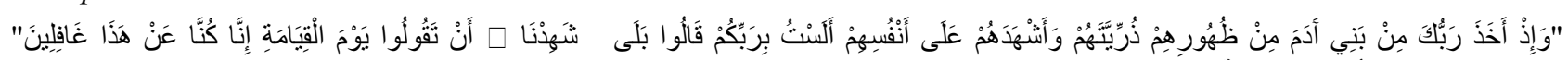

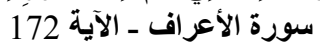

[Shakir 7:172] And when your Lord brought forth from the children of Adam, from their backs, their descendants, and made them bear witness against their own souls: Am I not your Lord? They said: Yes! we bear witness. Lest you should say on the day of resurrection: Surely we were heedless of this. 
[Pickthall 7:172] And (remember) when thy Lord brought forth from the Children of Adam, from their reins, their seed, and made them testify of themselves, (saying): Am I not your Lord? They said: Yea, verily. We testify. (That was) lest ye should say at the Day of Resurrection: Lo! of this we were unaware;

[Yusuf Ali 7:172] When thy Lord drew forth from the Children of Adam - from their loins - their descendants, and made them testify concerning themselves, (saying): "Am I not your Lord (who cherishes and sustains you)?"- They said: "Yea! We do testify!" (This), lest ye should say on the Day of Judgment: "Of this we were never mindful":

\section{Commentary:}

This Quranic verse anadiploses syntactically and semantically at the phrase “ " testify/ We do testify]. To recapitulate, the verse contains two sentences that are syntactically connected (1) ... Am I not your Lord? They said: Yes! we bear witness/ We testify. Hence, "we" refers to the children of Adam, and their descendants/reins. The speakers say "We testify" (2) We testify, lest you should say on the day of resurrection/ Judgment: Surely we were heedless of this. From this perspective, the angels do testify too on the occasion. They are eyewitnesses that would be a third party on the Day of Judgment. Evidently, the so called "reducing" anadiplosis emphasized the fact that both sentences are true by not repeating "We testify". It attributes an action to the third tenor "angles".

All translations failed to suggest the affective, allusive and stylistic meanings. However, the addition of (that was) and (This) in parentheses by M. Pickthall and Yusuf Ali respectively, saved some of the attitudinal and associative meanings.

\section{Example 5:}

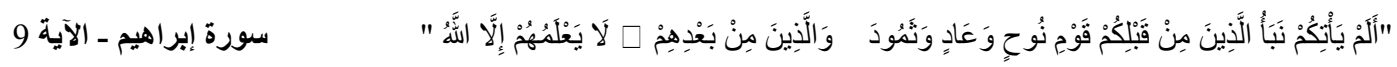

[Shakir 14:9] Has not the account reached you of those before you, of the people of Nuh and Ad and Samood, and those after them? None knows them but Allah. . .

[Pickthall 14:9] Hath not the history of those before you reached you: the folk of Noah, and (the tribes of) A'ad and Thamud, and those after them? None save Allah knoweth them. . .

[Yusuf Ali 14:9] Has not the story reached you, (O people!), of those who (went) before you? - of the people of Noah, and 'Ad, and Thamud? - And of those who (came) after them? None knows them but Allah. . .

\section{Commentary:}

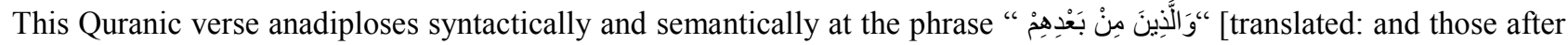
them/ And of those who (came) after them]. To analyze, the verse contains two sentences that are syntactically connected; (1) Hath not the history/ account/ stories of those before you reached you: the folk of Noah, A'ad Thamud, and those after them. The reference of "those" will be confined to the "joint" nations and generations that preceded Muhammad but followed Noah, 'Ahd, and Thamode. Rationally, these nations are, hitherto, inaccurately chronicled. (2) And those after them, None knows them but Allah. This transcendental knowledge is including all the generations of the human mankind. Statistically, it is not knowledgeably possible to none of the creatures to count them all or to measurably count the entire human breed ever been on the earth. Evidently, the so called "reducing" anadiplosis emphasized the fact that both sentences are true by not repeating "and those after them".

All translations failed to suggest the affective, allusive and stylistic meanings. Again, Yusuf Ali has oddly used double punctuation marks (? -) that served the syntactic and affective meaning the best in addition to sectioning the block question into smaller units; repeating the question mark every time that summed up to the associative meaning. This individual conduct ensures his exquisite taste and sensitivity to the eloquent and rhetorical Quranic discourse.

\section{Example 6:}

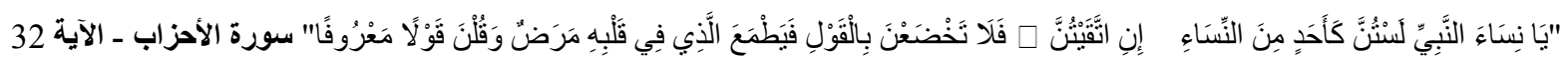

[Shakir 33:32] O wives of the Prophet! you are not like any other of the women; If you will be on your guard, then be not soft in (your) speech, lest he in whose heart is a disease yearn; and speak a good word.

[Pickthall 33:32] O ye wives of the Prophet! Ye are not like any other women. If ye keep your duty (to Allah), then be not soft of speech, lest he in whose heart is a disease aspire (to you), but utter customary speech.

[Yusuf Ali 33:32] O Consorts of the Prophet! Ye are not like any of the (other) women: if ye do fear (Allah), be not too complacent of speech, lest one in whose heart is a disease should be moved with desire: but speak ye a speech (that is) just.

\section{Commentary:}

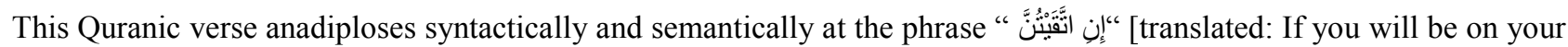
guard/ If ye keep your duty/ if ye do fear]. To recapitulate, the verse contains two sentences that are syntactically connected. The two sentences address the wives of the prophet, peace and mercy be upon him, saying (1) You are not like any other women, if you keep your duty (to Allah)/ fear (Allah)/ if you will be on your guard. (2) If you will be on your guard, be not soft in (your) speech! Apparently, the so called "reducing" anadiplosis emphasized the fact that both sentences are true by not repeating "if you will be on your guard". 
Pickthall's translation conceded only the first meaning without any consideration to the associative meaning of the next juncture when he translated "Ye are not like any other women. If. .." and so did Shakir by capitalizing "If" and by the ambiguous use of "then". The smart use of punctuation marks, of the colon to end the first clause and the comma after the connecting phrase, makes Yusuf's translation the best of them. Yet, it does without the allusive, emphatic and stylistic meanings.

\section{Suggested strategies}

Toward a successful rendering of the affective, attitudinal, allusive, emphatic, stylistic and associative meanings, two strategies are suggested:

(1) To keep it simple and straight by recapitulating the equivalent device; to reduplicate the word(s) in square brackets [sics]. This is diagrammatically rendered as _ 1 w, $\mathbf{w},[\mathbf{w}] 2$.

(2) To keep it simple and short by marking the word(s) either via enclosing them by two semicolons, Colons or even "asterisms". This technique is to be initially introduced, charted or eventually notified]. This is diagrammatically

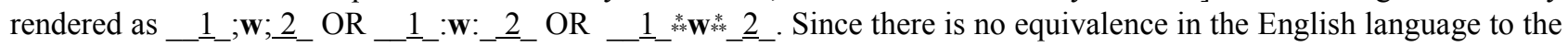
so-called "reduced" anadiplosis, it necessitates inventing a novice punctuation marker.

\section{Conclusion}

6.1 The use of anadiplosis is comparable in English and Arabic. Both Arabic and English languages, among many other languages, employ rhetorically the use of anadiplosis. The Arabic languages, moreover, embraces an additional variant as described.

6.2 The so-called "reduced" anadiplosis is serving emphatic and linking purposes. Its use is observed in stylistically distinguished texts.

6.3 Most of the available Quranic translations failed to successfully render the "reduced" anadiplosis into English. Yet, Yusuf Ali's is always the nearest. The inaccurate translation of the "reduced" anadiplosis in Quran passively affects the semantic and stylistic levels with a mild distortion of the textual level.

6.4 The abovementioned strategies are highly suggested toward a faithful translation of the Quranic "reduced" anadiplosis.

\section{Acknowledgement}

I am pleased to gratefully acknowledge my first English Teacher: Mr. Emam Mustafa, the spiritual teacher: Prof. M. Fethullah Gülen and my close friend, the witty linguist, Ms. Esra'a Mustafa. Thank you all for your ultimate pedagogical guidance.

\section{References}

Pickthall, M. W. (2000) The Glorious Qur'an: Translation. Elmhurst, NY: Tahrike Tarsile Qur'an.

Shakir, M. S. (2001) The Glorious Quran: With Translation and Transliteration. Qum: Ansariyan Publications.

Ali, A. Y. (1977) The Glorious Qur'an = Al-Qur'ān Al-Karīm: Translation and Commentary. Indianapolis: Published by American Trust Pubns. for the Muslim Student's Association of the United States \& Canada.

$$
\text { القرءان الكريم (رواية حفص عن عاصم) (1999): مر اجعة مجمع البحوث الاسلامية بالقاهرة- المطابع الأميرية. }
$$

Bernard, M. (eds.) (1991). A Dictionary of Literary Devices: Gradus, A-Z

Bussmann, H., Trauth, G. and Kazzazi, K. (1999). Routledge Dictionary of Language and Linguistics. London: Routledge.

Chris Baldick $3^{\text {rd }}$ ed. (2009): The Oxford Dictionary of Literary Terms , Oxford University Press;

Cuddon J. A., Preston, C. E. $4^{\text {th }}$ ed. (2000). The Penguin Dictionary of Literary Terms and Literary Theory (Penguin Dictionary), Penguin Books.

Dickins, J., Hervey, S. and Higgins I. (2002). Thinking Arabic Translation: A Course in Translation Method: Arabic to English, London: Routledge Taylor \& Francis group.

Hernández, M. (2001). The Selected Poems of Miguel Hernandez: A Bilingual Edition. Genoways, T. (ed). Chicago:The University of Chicago Press.

Lawrence, D. H. (1976). The Complete Short Stories. New York: Penguin.

Khan, M. M. (1996). The English Translation of Sahih Al Bukhari, USA: Al-Saadawi Pubns

Maeterlinck, M. (2003) Hothouses: Poems 1889. Translated by: Howard, R. Princeton: Princeton University Press.

Milton, J. (2009). John Milton Complete shorter poems with original spelling and punctuation. Revard, S., P, (ed).

Chichester: Willy-Blackwell.

Nabokov, V. (2010). Lolita. New York: Knopf Doubleday Publishing Group. 
Preminger, A. and Brogan, T.V. (eds.) (1993). The New Princeton Encyclopedia of Poetry and Poetics, Princeton: Princeton University Press.

Thompson, G. ( ${ }^{\text {rd }}$ ed) (2013). Introducing Functional Grammar, London: Routledge.

\section{Online resources}

"Song of Myself (1892 Version)." Poetry Foundation [Online] Available:

http://www.poetryfoundation.org/poem/174745 (Retrieved on July 29 $9^{\text {th }}, 2014$ ).

Odyssee Theater - Goethe." ODYSSEE Theater - Goethe. [Online] Available:

http://odysseetheater.org/goethe/texte/gedichte_vermischte.htm (Retrieved on July 29th, 2014).

"Sonnet CXXIX." [Online] Available: http://shakespeare.mit.edu/Poetry/sonnet.CXXIX.html (Retrieved on July 29th, 2014).

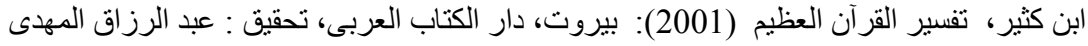

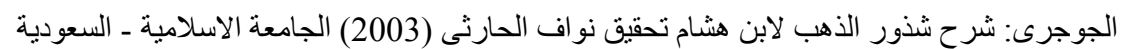

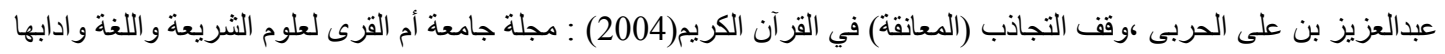

$$
\begin{aligned}
& \text { جزء } 19 \text { عدد } 31 \text {. }
\end{aligned}
$$

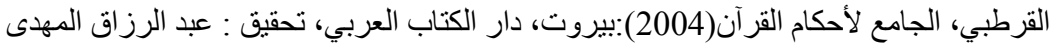

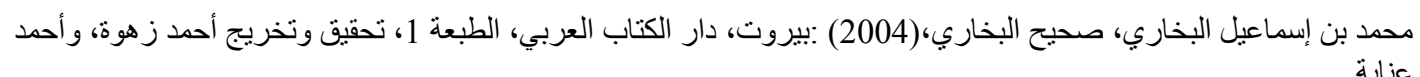

